УДК 355.233.004

DOI https://doi.org/10.24919/2308-4863/34-2-34

Іван ГОНЧАРЕНКО, orcid.org/0000-0002-6883-4170 кандидат педагогічних наук, заступник начальника з морально-психологічного забезпечення Украӥнської військово-медичної академії (Київ, Украӥна)i_goncharenko71@ukr.net

Володимир ШПОРТЬКО, orcid.org/0000-0002-0805-4922 викладач кафедри загальновійськових дисииплін

Української військово-медичної академії (Київ, Україна) volodimir2000@yahoo.com

\title{
РЕЗУЛЬТАТИ ЕКСПЕРИМЕНТАЛЬНОЇ ПЕРЕВІРКИ ОРГАНІЗАЩЙНО-ПЕДАГОГІЧНИХ УМОВ РОЗВИТКУ ПРОФЕСІЙНОӤ КУЛЬТУРИ МАЙБУТНІХ ВІЙСЬКОВИХ ЛІКАРІВ У СИСТЕМІ ВІЙСЬКОВО-МЕДИЧНОЇ ОСВІТИ
}

У статті висвітлюється методика і результати проведеного експериментального дослідження із вивчення стану та розвитку професійної культури майбутніх військових лікарів у системі військово-медичної освіти. Автори статті розкривають результати констатуючого, контрольного і формувального експериментів, у яких взяли участь студенти медичних університетів Украӥни, які проходили військову підготовку у медичних університетах, і слухачі Української військово-медичної академії.

У статті здійснено аналіз останніх досліджень і публікаиій вчених, які розкривають суть поняття «професійна культура», висвітлено аналогічні розробки в галузі військово-медичної освіти Украӥни. Здійснюючи власну експериментальну перевірку, автори спираються на теоретичні напрацювання науковців, у яких розкрито методику «педагогічного експерименту». Протягом педагогічної діагностики було застосовано такі методи дослідження: незалежна експертна оцінка групою експертів, спостереження, анкетування, бесіда, інтерв'ю.

Завданням педагогічного експерименту була перевірка гіпотези дослідження розвитку професійної культури лікарів шляхом створення відповідних організаційно-педагогічних умов, в яких автори передбачають впровадження когнітивної-спрямованої технології, застосування експлічитно-психологічного впливу на студентівмедиків. У статті автори здійснюють аналіз результатів етапів проведення констатуючого і формувального експерименту, щзо дає змогу встановити стан педагогічної системи, яка вивчається, реальний рівень сформованості і розвитку професійної культури студентів. За результатами експериментального дослідження було виявлено причинно-наслідкові зв'язки у тривалості педагогічного процесу, відбуватиметься подальша дослідницька робота, щзо дає змогу впроваджувати нову педагогічну технологію, спрямовану на покращення результатів у навчанні і вихованні студентів медичних університетів та слухачів УВМА.

Стан розвитку професійної культури майбутніх військових лікарів було досліджено за допомогою таких структурних компонентів професійної культури: когнітивного, комунікативного, мотиваційно-ціннісного, морально-етичного, етнокультурного і організаційного. Висновки дослідження, використані у впровадженні педагогічних технологій, дозволяють у подальшому корегувати методику процесу навчання майбутніх військових лікарів, продовжувати пошуково-експериментальну роботу з метою покращення форм і методів навчання студентів, набуття ними достатніх професійних навичок і вмінь.

Ключові слова: експериментальна перевірка, професійна культура, розвиток, педагогічна діагностика, організаційно-педагогічні умови, майбутні військові лікарі. 
Ivan GONCHARENKO, orcid.org/0000-0002-6883-4170

Candidate of Pedagogical Sciences, Deputy Chief of the Moral and Psychological Support Military Medical Academy of Ukraine (Kyiv,Ukraine)i_goncharenko71@ukr.net

Volodymyr SHPORTKO, orcid.org/0000-0002-0805-4922 Lecturer at the Department of General Military Disciplines Military Medical Academy of Ukraine (Kyiv, Ukraine) volodimir2000@yahoo.com

\title{
RESULTS OF EXPERIMENTAL VERIFICATION OF ORGANIZATIONAL AND PEDAGOGICAL CONDITIONS OF DEVELOPMENT OF PROFESSIONAL CULTURE OF FUTURE MILITARY DOCTORS IN THE SYSTEM MILITARY MEDICAL EDUCATION
}

\begin{abstract}
The article highlights the methodology and result of an experimental study and development of professional culture of future military doctors in the system of military medical education. In the article the author highlights the results of the ascertaining, control and molding experiments in which took part students of medical universities who were undergoing military training at Ukrainian medical universities and Ukrainian Military Medical Academy.

The author of the article analyzed the latest research and publications of scientists that reveal the essence of the concepts of "professional culture", highlighted similar developments in the field of military medical education in Ukraine. Carrying out his own experimental verification, the author relies on the theoretical achievements of scientists who have revealed the method of "pedagogical experiment". During the pedagogical diagnostics were used such research methods as independent expert evaluation by group of experts, observation, questionnaires and interviews.

The task of pedagogical experiment as a whole was to test the hypothesis of research of development of professional culture of doctors, by creation of the corresponding organizational and pedagogical conditions where the author provides introduction of cognitive-directed technology, application of explicitly psychological influence to medical students. In this article the author highlights the results of experiment, which is the initial in the experimental study, and allows establishing the state of the pedagogical system being studied, the real level of formation and development of professional culture of students. According to the results of ascertaining experiment, causal and consequential connections of the pedagogical process are revealed, further research work is carried out, which aims to introduce new pedagogical technology in order to improve the results in teaching and educating students of medical universities and students of UMMA.

The state of formation and development of professional culture of future military doctors was studied using such structural components of professional culture as: cognitive, communicative, motivational-value, moral-ethical, ethno cultural and organizational. The conclusions of study will contribute to the search for more effective pedagogical technologies, the achievement of quality in students' knowledge, the acquisition of sufficient professional skills and abilities.
\end{abstract}

Key words: experimental verification, professional culture, development, pedagogical diagnostics, organizational and pedagogical conditions, future military doctors.

Постановка проблеми. Сучасний етап розвитку Збройних Сил України і Медичних сил України гостро потребує вдосконалення системи військово-медичної освіти, проведення дослідження щодо розвитку професійної культури науково-педагогічних працівників, студентів і слухачів вищих медичних закладів України. В умовах поглиблення євроінтеграції освітнього процесу країни, наближення системи військово-медичної освіти до євроатлантичних стандартів і досягнення якісних показників у підготовці майбутніх військових лікарів виникає необхідність проведення експериментальних досліджень щодо розвитку професійної культури.
Аналіз досліджень. У контексті формування і розвиткупрофесійноїкультурилікарівувагупривертають дослідження Е. Белоконева, Ю. Вороненка, О. Гури, Н. Миколаєнка, О. Мінцера, В. Краснова, О. Кульбаха, О. Парахіна. Питанням удосконалення кваліфікації викладачів військово-медичної освіти присвячені роботи Я. Радиш, А. Романенка i В. Солярика. Особливості підготовки військових лікарів у системі військово-медичної освіти і підвищення їх професійного рівня системно розкриті у працях М. Бойчака, Л. Голіка, В. Жаховського, Б. Клішевича, Ю. Румянцева.

Педагогічна діагностика та експериментальна перевірка підготовки майбутніх спеціалістів 
у теорії і практиці педагогіки розкриті у працях відомих педагогів С. Архангельського, Ю. Бабанського, В. Журавльова, В. Міхеєва, А. Піскунова. Методика педагогічного дослідження і експерименту, обробка їх результатів викладені у роботах П. Волкова, Б. Гершунського, С. Гончаренка, I. Підласного, В. Ягупова. Однак проблема формування професійної культури майбутніх військових лікарів в умовах російсько-української війни на сході України та пандемії COVID-19 залишається не досить розробленою.

Мета статті - визначення методики і висвітлення результатів експериментальної перевірки iз формування та розвитку професійної культури майбутніх військових лікарів. Проведена експериментальна перевірка ставила за мету перевірку гіпотези дослідження щодо розвитку професійної культури, насамперед свідомості військових лікарів у ставленні до виконання своїх обов'язків, шляхом створення відповідних організаційно-педагогічних умов, впровадження когнітивно-спрямованої технології, застосування експліцитно-психологічного впливу на студентів медичних закладів.

Виклад основного матеріалу. Сучасний етап формування і розвитку Медичних сил Збройних Сил України в умовах військової агресії Російської Федерації, поширення інфекційних захворювань, які зростають до критичного рівня, потребують належної оцінки стану і перспектив підготовки майбутніх військових лікарів у системі військово-медичної освіти, яка повинна бути інтегрована в освітній процес Європейського співтовариства та відповідати стандартам військової освіти країн НАТО.

Світова федерація медичної освіти (СФМО / WFME) у стандартах якості післядипломної освіти визнає, що рівень підготовленості медичного працівника не повинен залежати від локальної політики будь-якої країни, а бути прозорим і визнаним на міжнародному рівні. Зона Європейської вищої освіти повинна будуватися на європейських культурних традиціях відповідальності освіти перед суспільством; на широкому і відкритому доступі до базової та післядипломної освіти; на освіті, спрямованій на всебічний розвиток особистості, та навчанні протягом усього життя.

Виникає необхідність отримання обгрунтованих наукових результатів щодо педагогічної оцінки системи підготовки військових лікарів шляхом впровадження низки педагогічних досліджень. 3 метою вивчення окремих сторін професійної культури майбутніх військових лікарів, дослідження висунутої гіпотези щодо моделі і методики іiї розвитку постає потреба проведення педагогічного експерименту, пошуку нової сучасної технології педагогічного процесу, виявлення необхідних умов реалізації завдань щодо якісної підготовки майбутніх військових лікарів в умовах сьогодення.

Бабанський визначає поняття «педагогічний експеримент» як комплекс методів дослідження для перевірки вірогідності педагогічних гіпотез». $\mathrm{У}$ роботі «Проблеми підвищення ефективності педагогічних досліджень» дослідник наводить методику щодо методу педагогічного експерименту (Бабанський, 1982: 99-100).

Педагогічна наука широко використовує теоретичні засади в галузі експериментальних педагогічних досліджень вчених Ю. Бабанського, С. Гончаренко, О. Данилова, В. Загвязинського, Л. Занкова, А. Піскунова, Н. Кузьміна. С. Гончаренко наводить розгорнуту форму педагогічного експерименту, який повинен спиратися на весь арсенал дослідницьких методів, що призводить до нагромадження емпіричного матеріалу, забезпечує перехід від спостереження до глибокого пізнання і вироблення практичних рекомендацій (Гончаренко, 2008: 178).

Розглядаючиметодикуекспериментальноїперевірки організаційно-педагогічних умов формування професійної культури, необхідно зазначити що метою експериментальної роботи була перевірка основних теоретичних положень дисертації, оцінювання ефективності моделі і методики формування професійної культури майбутніх військових лікарів у системі військово-медичної освіти.

На початку дослідження було складено планпрограму експериментальної роботи, здійснення якої була розраховано із 2017 по 2020 роки. Завданням педагогічного експерименту було з'ясування порівняльної ефективності застосованих у педагогічній практиці методів, технологій, нових прийомів, форм роботи. В межах цього дослідження постало завдання визначити рівень сформованості і розвитку професійної культури майбутніх лікарів у системі військово-медичної освіти.

За типологією проведення експерименту на початку дослідження було здійснено вивчення документів, наукової літератури, проблематику із станом професійної культури лікарів, в тому числі країн НАТО та СС (Шпортько, 2020: 389-402). Були уточнені основні поняття щодо змісту і суті професійної культури у теорії і практиці досліджень, після чого у 2018 році було проведено констатуючий експеримент (Шпортько, 2020: 32-36). Результати констатуючого експерименту дозволили встановити стан предмету дослідження, вия- 
вити рівень сформованості і розвитку професійної культури майбутніх військових лікарів на початку ïх навчання у вищому медичному закладі з метою іiі подальшого розвитку і формування. Проміжний етап та контрольний експеримент (пізнавальнопошуковий) було проведено у 2019 році, а формуючий експеримент завершено у 2020 році.

У проведенні констатуючого експерименту iз вивчення кола питань формування i розвитку професійної культури майбутніх військових лікарів взяли участь 220 студентів Національного медичного університету імені О.О. Богомольця та Київського медичного університету усіх основних спеціалізацій медичних напрямів навчання. У другому етапі експерименту (пізнавальнопошуковому) взяли участь 430 студентів 3-4 курсів медичних університетів, а також слухачі першого курсу УВМА.

В етапі формуючого експерименту взяли участь 110 слухачів і викладачів УВМА. 3 метою проведення експерименту були використані такі методи дослідження: метод незалежної експертної оцінки групою експертів, методи спостереження, бесіди, анкетування і математичної обробки інформації. На етапі проведення контрольного експерименту до нього приєдналися слухачі першого курсу УВМА, які були прийняті в цей час на навчання в Українську військово-медичну академію із Вінницького, Запорізького, Одеського, Тернопільського, Івано-Франківського медичних університетів, що дало змогу охопити опитуванням представників усіх регіонів України.

У 2018 році під час констатуючого експерименту було уточнено існуючу систему організаційнопедагогічних умов 3 формування професійної культури майбутніх військових лікарів у системі військово-медичної освіти. Стан сформованості і розвитку професійної культури майбутніх військових лікарів було вивчено шляхом визначення рівня таких компонентів професійної культури: когнітивного, комунікативного, організаційного, моральноетичного, поведінкового і етнокультурного.

Першим досліджуваним показником проведеного нами констатуючого експерименту було визначення рівня сформованості і розвитку когнітивного компоненту професійної культури майбутніх військових лікарів. Результати засвідчили, що низький рівень розвитку когнітивного компоненту встановлено у $32 \%$ опитаних. Під час проміжного, контрольного експерименту низький рівень когнітивного компоненту дорівнював 25\%, а констатуючого - $15 \%$.

Середній рівень розвитку когнітивного компоненту протягом констатуючого етапу експери- менту показали 58\% опитаних. За результатом проміжного, контрольного експерименту середній рівень дорівнював $60 \%$, а на формувальному $65 \%$. Про значний розвиток високого рівня когнітивного компоненту свідчить його зростання за визначеними вище етапами експерименту: $10 \%$, $15 \%, 20 \%$. Варто зазначити, що велика шкала розбіжностей когнітивних показників виникає у студентів медичних закладів між групами, які навчаються на бюджетній формі навчання, і групами студентів, які навчаються на контрактній основі. Високі показники когнітивного компоненту показали значну умотивованість до навчання серед студентів факультету підготовки військових лікарів, у подальшому більша частина 3 них розпочала навчання в УВМА.

Комунікативна культура лікаря $\epsilon$ важливою частиною професійної культури і компетентності військового медика. Під час дослідження ми встановили, що комунікативна культура майбутнього лікаря формується на основі мотиваційних і особистісних компонентів, вияву загальної культури, комунікативних знань і навичок. Для визначення рівня сформованості комунікативного компоненту ми застосовували анкетування, спостереження, бесіди та інтерв'ю. Було використано методику «Виявлення комунікативних здібностей» (В. Бойка), діагностику здатності до співпереживання (С. Дідато), комунікабельності особистості (тест Ряховського).

Використовувалися анкети 3 питаннями відкритого і закритого типів, у яких студенти обирали альтернативну відповідь або висловлювали свої думки. За допомогою бесід і анкетування ми ретельно дослідили рівень набутих студентами комунікативних знань, те, як студенти розуміють усвідомлення потреби у підвищенні комунікативного рівня. Показники проведення дослідження комунікативного компоненту експерименту наведені утаблицізаетапами дослідження (увідсотках).

\begin{tabular}{|l|c|c|c|}
\hline & $\begin{array}{c}\text { Констату- } \\
\text { ючий }\end{array}$ & $\begin{array}{c}\text { Проміж- } \\
\text { ний }\end{array}$ & $\begin{array}{c}\text { Форму- } \\
\text { вальний }\end{array}$ \\
\hline Низький рівень & 25 & 20 & 14 \\
\hline Середній рівень & 53 & 49 & 51 \\
\hline Високий рівень & 22 & 31 & 35 \\
\hline
\end{tabular}

Констатуючий експеримент щодо виявлення рівня сформованості комунікативного компоненту показав, що низький рівень розвитку комунікаційних умінь і навичок присутній у $25 \%$ студентів і $\epsilon$ досить низьким для майбутніх військових лікарів. Середній показник комунікативного компоненту показали 53\% опитаних, високий було встановлено у $22 \%$ студентів. 
Серед комунікативних труднощів для студентів виявлені такі: страх аудиторії, хвилювання, нерішучість; низький рівень навичок у спілкуванні; неготовність вести діалог із викладацьким складом і студентами старших курсів. Вивчення комунікативних навичок, які будуть потрібні майбутнім військовим медикам, засвідчило їх неготовність до командно-адміністративного (керівного) стилю роботи із військовим колективом, статутної комунікації, військової субординації (під час занять із військово-спеціальної підготовки за програмою підготовки офіцерів запасу).

Досліджуючи мотиваційно-ціннісний складник професійної культури майбутніх військових лікарів у процесі констатуючого експерименту, ми опиратися на психологічні аспекти професійного становлення і досліджували мотиви, які спонукали особистість до обрання професії. Варто погодитися із думкою науковців О. Бодальова і О. Черних (Бодальов, Черних, 1983: 162), які дають оцінку мотивам під час вибору професії, серед яких матеріальна зацікавленість, прагнення зміцнити свій соціальний статус, бажання самостверджуватися та впливати на інших людей, наукові або альтруїстичні інтереси.

Ми застосовували методику «Ціннісні орієнтації» М. Рокіча (Райгородский, 2006: 246). Студент мав проаранжувати низку цінностей, притаманну професії лікаря, за значимістю. Опитуваним було запропоновано розділити ціннісні мотивації лікаря на три групи: необхідні, корисні і неприпустимі. Було запропоновано проаранжувати i мотиви щодо здобуття професії лікаря та якісного оволодіння фахом, які ми розділили на такі групи: прагматичні (матеріальна винагорода, зарплата, інші шляхи здобуття матеріальних благ); наукові мотиви (бажання сумлінно вчитися, набувати знань, навичок, умінь, робити наукові винаходи); альтруїстичні мотиви (якісне виконання обов'язків, покращення здоров'я пацієнтів).

Узагальнення результатів дало змогу визначити рівні мотиваційно-ціннісної сфери майбутніх військових лікарів у перший рік навчання, які було розділено на три рівні (низький, середній, високий). Показники проведення експерименту із дослідження мотиваційно-ціннісного компоненту наведені в таблиці (у відсотках).

\begin{tabular}{|l|c|c|c|}
\hline & $\begin{array}{c}\text { Конста- } \\
\text { туючий }\end{array}$ & $\begin{array}{c}\text { Проміж- } \\
\text { ний }\end{array}$ & $\begin{array}{c}\text { Форму- } \\
\text { вальний }\end{array}$ \\
\hline Низький рівень & 20 & 16 & 13 \\
\hline Середній рівень & 61 & 60 & 55 \\
\hline Високий рівень & 19 & 24 & 32 \\
\hline
\end{tabular}

Результати анкетування на етапі констатуючого дослідження показують, що низький рівень мотиваційно-ціннісного компоненту мали 20\% студентів, 61\% - середній і тільки 19\% - високий. Високий рівень розвитку готовності студента до роботи в якості лікаря зумовлений високою мотивацією у виборі професії, бажанням присвятити себе порятунку і лікуванню людей за будь-яких обставин. Низька мотивація свідчить на те, що не всі студенти самостійно прийняли свідоме рішення стати лікарем, значна частина 3 них опиралася на думку і рішення батьків. На початку дослідження значна частина респондентів головним мотивом своєї навчальної діяльності вважала отримання диплому із вищою освітою лікаря, тому ставлення до якісного навчання ще знаходилося на стадії розвитку. Деякий вплив на мотиваційно-ціннісний компонент розвитку професійної культури справив фактор росту пандемії COVID-19, який знижував мотивацію окремих майбутніх лікарів працювати у сфері спеціалізації лікаря-інфекціоніста.

Велике значення у підготовці майбутніх лікарів має формування морально-етичного складника професійної культури. Л. В. Богданова визначає професійну культуру як органічний сплав кваліфікації й моральності, що функціонує на основі трудової моралі (Богданова, 1998: 388). Серед сучасних дослідників цікавими $є$ роботи Х. Мазепи (організаційно-педагогічні умови виховної роботи в медичному коледжі) (Мазепа, 2001: 20), Л. Переймибіди (розвиток деонтологічної культури учнів медичного ліцею) (Переймибіда, 2008: 21).

Під час опитування щодо аспектів моральноетичної поведінки на етапах експерименту ми надали перелік питань 3 метою вивчення стану сформованості і розвитку професійних і етичних цінностей. Увага була звернута на проблему самооцінки морально-етичних якостей майбутнього лікаря у реальному середовищі. Мета була не тільки продіагностувати стан сформованості, а й дати молодій особі настанови щодо адекватної самооцінки 3 метою зменшення таких вад як егоцентризм, цинізм, байдужість, корисливість, задати орієнтири для подальшого самовдосконалення у деонтологічній культурі.

Дослідження морально-етичного компоненту наведені в таблиці (у відсотках).

\begin{tabular}{|l|c|c|c|}
\hline & $\begin{array}{c}\text { Констату- } \\
\text { очий }\end{array}$ & $\begin{array}{c}\text { Проміж- } \\
\text { ний }\end{array}$ & $\begin{array}{c}\text { Форму- } \\
\text { вальний }\end{array}$ \\
\hline Низький рівень & 23 & 19 & 15 \\
\hline Середній рівень & 62 & 56 & 50 \\
\hline Високий рівень & 15 & 25 & 35 \\
\hline
\end{tabular}


За показниками опитування констатуючого експерименту можна зазначити, що 23\% студентів показали низький рівень сформованості морально-етичного компоненту професійної культури як майбутнього лікаря, $62 \%$ - середній і лише $15 \%$ - високий. Під час формувального експерименту високий рівень морально-етичного компоненту збільшився до $35 \%$, середній дорівнював $50 \%$, низький $-15 \%$.

Важливим було вивчення етнокультурного рівня студентів і його самооцінка. Питання опитування були зосереджені на визначенні обізнаності і рівня набутих знань з історії України, українського війська, народних традицій, пісень. Було вивчено рівень активності студентів щодо їх участі у конкурсах, фестивалях, обговоренні телевізійних і радіо передач, читанні книг, ставленні до державної мови і ії використання. Дослідження етнокультурного компоненту наведено в таблиці (у відсотках).

\begin{tabular}{|l|c|c|c|}
\hline & $\begin{array}{c}\text { Констату- } \\
\text { ючий }\end{array}$ & $\begin{array}{c}\text { Проміж- } \\
\text { ний }\end{array}$ & $\begin{array}{c}\text { Форму- } \\
\text { вальний }\end{array}$ \\
\hline Низький рівень & 30 & 20 & 15 \\
\hline Середній рівень & 55 & 52 & 45 \\
\hline Високий рівень & 15 & 28 & 40 \\
\hline
\end{tabular}

У процесі констатуючого експерименту низький рівень етнокультурного компоненту показали $30 \%$ опитуваних, $55 \%$ - середній, $15 \%$ - високий. Аналіз засвідчує, що етнокультурне середовище дуже впливає на культуру студентів. В УВМА була спланована і проведена предметна культурологічна робота із розвитку етнокультурного напряму професійної культури, що позитивно змінило показники. На формувальному етапі експерименту високий рівень уже дорівнював $40 \%$, що свідчить про якісне покращення показника етнокультурного рівня удвічі, низький рівень зменшився удвоє, а середній - залишився майже без змін.

Вивчаючи організаційний компонент, ми ставили за мету з'ясувати вміння майбутнього лікаря самостійно організувати як власну роботу, так і роботу невеликої групи колег. Дослідження організаційного компоненту наведено в таблиці (у відсотках).

\begin{tabular}{|l|c|c|c|}
\hline & $\begin{array}{c}\text { Констату- } \\
\text { очий }\end{array}$ & $\begin{array}{c}\text { Проміж- } \\
\text { ний }\end{array}$ & $\begin{array}{c}\text { Форму- } \\
\text { вальний }\end{array}$ \\
\hline Низький рівень & 22 & 15 & 12,5 \\
\hline Середній рівень & 54 & 59 & 58 \\
\hline Високий рівень & 24 & 26 & 29,5 \\
\hline
\end{tabular}

Під час констатуючого експерименту $22 \%$ респондентів показали низький рівень організаційних навичок, що свідчить про неготовність окремих студентів працювати в команді, брати участь у масових організаційних заходах, виявляти ініціативу та лідерські якості. У 54\% респондентів визначено середній рівень організаційних навиків і лише у $24 \%$ - високий. Студенти 3 високим рівнем організаторських здібностей займалися волонтерською роботою, активно брали участь у громадському житті колективів, включилися у роботу студентської ради. Варто підкреслити, що низький рівень організаційного компоненту на етапі формувального експерименту зріс удвічі.

Ми провели експериментальне дослідження із визначення сформованості і розвитку професійної культури майбутніх військових лікарів у системі військово-медичної освіти. Узагальнюючи результати опитування під час констатуючого експерименту, було встановлено, що високий рівень мають $17,5 \%$ опитаних студентів, низький $25,3 \%$, середній $-57,1 \%$. Було використано методи незалежних експертних оцінок, спостереження, анкетування та інтерв'ю. Результати формуючого експерименту свідчать, що протягом навчання у медичних університетах і в УВМА високий рівень сформованості і розвитку професійної культури виявлено у $31,9 \%$ опитаних студентів, низький - у 14,08\%, середній - у 54\%. Відбулися якісні зміни у рівнях сформованості і розвитку професійної культури майбутніх військових лікарів.

Висновки. Отримані результати проведеного експерименту дозволили дослідити динаміку i розвиток професійної культури майбутніх лікарів у системі військово-медичної освіти. Результати дослідження $є$ підгрунтям для впровадження методичних рекомендацій із розвитку професійної культури майбутніх військових лікарів для науково-педагогічних працівників системи військово-медичної освіти.

Продовження роботи у напрямі покращення культури лікарів $\epsilon$ актуальним в сучасних умовах, зважаючи на потребу в якісній підготовці майбутніх військових лікарів, існуючі загрози, особливо 3 епідеміологічної обстановки, зокрема щодо розповсюдження COVID-19. Висновки і практичні рекомендації дослідження сприятимуть впровадженню нових методик, удосконаленню навчальних програм і застосуванню нових педагогічних технологій з метою підвищення загального рівня розвитку професійної культури майбутніх військових лікарів, покращенню їхніх знань, умінь і навичок. 


\footnotetext{
СПисок викоРИстАнИХ джЕРЕЛ

1. Бабанский Ю. К. Проблемы повышения эффективности педагогических исследований. (Дидактический аспект) : монография. М. : Педагогика, 1982. 192 с.

2. Гончаренко С. У. Педагогічні дослідження: методологічні поради молодим науковцям. Київ-Вінниця : ДОВ «Вінниця», 2008. 278 с.

3. Шпортько В. О. Проблеми формування професійної культури і компетентності майбутніх військових лікарів в медичних університетах країн НАТО. Збірник наукових пращь «Військова освіта». К. : НУОУ, № 2(42), 2020. С. $389-402$.

4. Шпортько В. О. Експериментальна перевірка організаційно-педагогічних умов розвитку професійної культури майбутніх військових лікарів у системі військово-медичної освіти. Вид. Інноваційна педагогіка, № 26, Одеса, 2020. С. 32-36.

5. Бодальов А. А. Личность и общение. М. : Педагогика, 1983. 256 с.

6. Райгородский Д. Я. Практическая психодиагностика: методики и тесты. М., 2006. 480 с.

7. Богданова Л. В. К вопросу о культуре профессионального общения. Юбилейный сб. тр. ученых. РГАФК., посв. 80-летию академии. М., 1998. 388 с.

8. Мазепа Х. П. Організаційно-педагогічні умови виховної роботи в медичному коледжі : автореферат дис. канд. пед. наук. 2001. 20 с.

9. Переймибіда Л. В. Організаційні засади діяльності педагогічного колективу з розвитку деонтологічної культури учнів медичного ліцею : автореферат дис. канд. пед. наук. К., 2008. 21 с.
}

\section{REFERENCES}

1. Babanskyi U. K. Problemy povishenija efektivnosti pedagogitheskih issledovaniy. (Didaktitheskiy aspect) : monographia [Problems of increasing the effectiveness of educational research]. (Didactic aspect) : monograph. M. : Pedagogika. 1982. 192 p. [in Russian].

2. Goncharenko S. U. Pedagogitchni doslidjenia: metodologitchni poradi molodim utchenim. [Pedagogical research: Methodological advice for young scientists]. Kyiv-Vinnitsa : DOV "Vinnitsa", 2008. 278 p. [in Ukrainian].

3. Shportko V. O. Problemy formuvannia profesiynoi kulturi i kompetentnosti majbutnih viiskovih likariv v medicthnih universitetah krain NATO. [Problems of formation of professional culture and competence of future military doctors in medical universities of NATO countries]. Collection of scientific works "Military education”. K. : NUODU, № 2(42), 2020. P. 389-402 [in Ukrainian].

4. Shportko V. O. Eksperementalna perevirka organizatsijno-pedagogitchnih umov rozvitku profesiynoi kulturi majbutnih viiskovih likariv u sistemi vijskovo-medithnoi osviti. [Experimental verifications organizational and pedagogical conditions of the development of professional culture of future military doctors in the system of military medical education]. Publication Innovative pedagogy, № 26. Odesa, 2020. P. 32-36 [in Ukrainian].

5. Bodaliov A. A. Litchnost i obshenie. [Personality and communication] M. : Pedagogika, 1983. 256 p. [in Russian].

6. Raigorodskyi_D. A. Praktitheskaja psihodiagnostika: methodiki i testi. [Practical psychodiagnostics: techniques and tests]. M., 2006. 480 p. [in Russian].

7. Bogdanova L .V. K voprosu o culture profesionalnogo obshenia. Jubileiniy sb. tr. utchenih. RGAFK., posv. 80-letiju akademii. [On the question of the culture of professional communication]. Jubilee collection of work of scientists. RGAPC. Dedicated to the 80 th anniversary of the Academy. M., 1998. 388 p. [in Russian].

8. Mazepa H. P. Organizatsiyno-pedagogithni umovi vihovnoi roboti v medihnomu koledji: [Organizational and pedagogical conditions of educational work in the medical college]. Auhor's abstract dis. Cand. of ped. Science. 2001.20 p. [in Ukrainian].

9. Pereimibida L .V. Organizatsijni zasadi dijalnosti pedagogithnogo kolektivu z rozvitku deontologithnoi kulturi uthcniv medihnogo litseiy: [Organizational based of activity of pedagogical collective on development of deontological culture of peoples of medical lyceum]. Auhor's abstract dis. Cand. ped. Science. K., 2008. 21 p. 